AGRICULTURE AND BIOLOGY JOURNAL OF NORTH AMERICA

ISSN Print: 2151-7517, ISSN Online: 2151-7525, doi:10.5251/abjna.2013.4.2.103.109

(C) 2013, ScienceHu $\beta$, http://www.scihub.org/ABJNA

\title{
Conventional and organic cropping systems of farming in Osun State of Nigeria
}

\author{
Lamidi W. Agunbiade
}

\author{
Dept. of Agronomy, College of Agriculture, Ejigbo Campus, Osun State University, Osogbo. \\ ABSTRACT
}

\begin{abstract}
Plot OG was organically cultivated while maximum tillage system with the use herbicides was employed for plot CN. There were three replicates for each: OG1, OG2, OG3 and CN1, CN2, CN3. Cassava stems were planted with other same treatments. The effectiveness of the conventional $(\mathrm{CN})$ and the organic $(\mathrm{OG})$ farming were compared using the heights of the crops and weeds on the plots relative to the number of days and the weeds densities. Leaf Area Index (LAI) and yield of the tubers per acre were also measured. The results show significant effects $(p<$ 0.05 ) of weeding methods observed ( $p=0.008$ and 0.000$)$ on the recorded weeds' heights; no significant effects $(p>0.05)$ of weeding methods were observed $(p=0.269)$ on weeds' density in plot OG but was observed $(p<0.05)$ in plot $C N$. At 270 th day, the percentage of LAl increment for the conventional over the organic was $39.89 \%$. The regression analysis shows stronger relationship between methods of farming and crop heights average values, $R^{2}=0.998$ and 0.999 . Plot $\mathrm{CN}$ had the highest figure of merit, $214 \%$ for conventional than organic. The total yield was $118 \%$ increased for the chemically weeded plot $\mathrm{CN}$ over the manually weeded plot OG.
\end{abstract}

Keywords: conventional farming, herbicides, LAI, organic farming, yield

\section{INTRODUCTION}

Organic farming first came into use in the United States in the 1940s, however, organic crop production did not begin to really develop as an industry until the 1970s (University of Kentucky Cooperative Extension Service -UKCES, 2011). In the early decades of the organic movement there were no uniform standards. This changed with the passage of the Organic Foods Production Act in 1990 and the implementation of mandatory certification requirements in 2002. In Nigeria, organic farming has been practiced ever since, even some farmers have never changed their form of farming, they never use conventional that is widespread now, not only because of cost of inputs but also because of their level of poverty, illiteracy and ignorance (Lamidi, 2005). Organic crop production is today one of the fastest growing segments of agriculture (UKCES, 2011). Organic farming has recently been favoured and encouraged by many in lieu of the present conventional farming system for conservation of soil, provision of quality food crops of natural origin and reduced cost.

Managing insect pests, plant diseases and weeds are the greatest challenge in organic farming. Pest management in organic fields emphasizes prevention through good production and cultural methods. Such goal is not a complete elimination of a pest but rather to manage pests and diseases to keep crop damage within acceptable economic levels. One of such management is a healthy soil that helps to build up organic matter in some number of years and improve soil quality.

Spraying of pesticide in agriculture for pest control is of diverse ways and means with each having its own desire ends. It is done on the soil as treatment to deter the emergency of weeds or kill the growing weeds or its seed (Magani and Shave, 2011). Controlling of weeds in a farm helps to ensure the seed viability, to guide against invasion of pests, to protect seedlings, and on the grown-up crops like cash crops to prevent outbreak of diseases by killing the pathogens or simply to control their diseases (American Society of Agronomy-ASA, 2009). The chemicals necessary to destroy weeds and insects or to treat the soil or the seed to fight soil borne or air borne diseases are a potent formulation in order to be effective (Olabode et al, 2011). If a chemical remain potent on the soil or plant, further applications are not to be made, in any case, environmental and other side effects are strongly related to continuity of chemical use. Sprayers are classified according to their application rate in litre/ha. Some are manually operated equipment of low volume application rate of about 50-200 litres/ha in the form of mists and fine sprays (MoE.BC, 2006). Others are power operated sprayer or motorized with about 200- 600 litre/ha 
capacity, tractor mounted and aerial spraying of medium and coarse sprays of between 200 and 600 litre/ha and greater than 600 litre/ha respectively. The various herbicides available in Nigerian market include paraquat dichloride (Weed crusher), Glyphosate (Clear weed), Triazine \& Chloroacetamide (primextra II magnum), Butchor (2Chloro-2, 6,-dimethyl-N-(butoxymethyl) acetalinide), atrazine (Triazine), Bipyridylium (Gramozone), gramoron (2,4-dimetrazine) and others (WSSA, 2011).

Cassava is a root crop with erect stem of about 2 metres height which unlike yam (-a pure tuber crop that craws and climb), has its roots swollen up to give food for man and beasts. It is grown in Nigeria and at an average of 43 million metric tonnes, processed raw cassava was exported to Asian countries for starch making and chips production and flour for bread. Manually weeding of cassava plot can be done in two major ways; cultivation with land preparation and hoeing after planting. According to CSAD (2005), the first weeding in cassava production is done at 4 weeks of age, followed by second weeding at 10 weeks and the third and final weeding is usually carried out at 16 weeks after planting, then they would have formed canopy which will not allow weeds to grow.

At the formation of canopy by cassava plants, its Leaf Area Index (LAI) defined as the leaf area per unit ground area needs to be measured for its performances and was calculated from measured data. It is a measure of the leafiness of a crop, in term of cassava, the level of formed canopy. LAl can be assessed directly through repeated area measurements on 'single leaves' and area accumulation, these methods are hence considered the most accurate (Chen et al., 1997), and for that reason they are often implemented as calibration tools for indirect measurement techniques (Cutini et al., 1998). It consists of destructive sampling of a small amount of representative crops out of the stands, from which the leaf area and vertical distribution of leaf area were measured leaf by leaf.

Organic farming has recently been favoured (Chavas et al., 2009) and farmers have been encouraged to practice it in lieu of conventional farming, this according to them will help for soil conservation, provision of quality food in term absence of synthetic materials in food and reduction in cost of operations. The objectives of this study were to investigate the economic benefits of the conventional and organic systems of farming on the cassava plants in their first five to six months.

\section{MATERIALS AND METHODS}

Experimental design: Two factors namely organic farming (OG) and conventional farming (CN) each with three replicates (OG1, OG2, OG3 for organic and $\mathrm{CN} 1, \mathrm{CN} 2, \mathrm{CN} 3$ for conventional) making a $2 \times 3$ factorial design experiment was used. Farm plots $\mathrm{OG}$ and $\mathrm{CN}$, each of $1 \frac{1}{2}$ acre (approximately $6000 \mathrm{~m}^{2}$ ) near one another were cultivated with each replicate having $1 / 2$ acre (approximately $2000 \mathrm{~m}^{2}$ ). Plot OG was manually cleared, tilled, cultivated, planted and weeded. The plot was based on minimal use of offfarm inputs and on management practice that restores, maintains and enhances ecological harmony (Chavas et al., 2009). Plot CN was mechanically cleared, tilled, cultivated, planted and chemically weeded after planting using systematic herbicide; Triazine \& Chloroacetamide (primextra II magnum) of 5 litres in 250 litres of water per hectares at 2 days after planting the cassava stems as preemergence herbicide. Plot $\mathrm{CN}$ was fumigated with nemagon which was deemed to be able to control nematodes and Bordeaux mixture to control the fungi as treatment of soils and air-borne diseases (Olabiyi, 2004). Before the experiment, both plots have been free of prohibited substances (e.g. synthetic pesticides and artificial fertilizers) for five years. The actual conversion from conventional agriculture to full organic production take from three to five years depending on the crops, soil fertility and the transition approach (UKCES, 2011).

Performances of the cassava crops : The cassava variety for the study was collected from IITA Ibadan, Nigeria, they were planted on the plots in March, fertilizer application was done 40 days after planting using NPK 15-15-15 fertilizer at $100 \mathrm{~kg} /$ acre. The choice of cassava variety planted was 98/0581, it been known for early maturing (IITA, 1990), ready for harvest after nine months, in the following December.

The various incurred costs for tillage, cassava planting, land rentage, tuber harvesting and other operations that are peculiar to both $\mathrm{OG}$ and $\mathrm{CN}$ plots were not taken into consideration separately but together as same operational costs in Table 3 and the subsequent calculations. The cost of weeding manually or using chemical, labour involved and other related that are not the same for both plots were taking into account, Table 3.

For the performances of the tubers, it starts from LAI measurements, the heights of the cassava plants and 
the effects of weeds on the crops via weeds' density and their heights.

Effects of Weeds on crops : The weed species on the plots were Tridax procumbens, Imperata cylindrica and Cyperus odorata. Systematic herbicide, Bipyridylium (Gramozone) was used as post emergency herbicide at 4 weeks, 10 weeks and 16 weeks for the first, second and third weeding respectively. Atrazine (Triazine), another preemergency herbicide could have been used, but it has been known to slightly reduce the emergence of cassava shoots and it also retard its growth for the first two to three weeks after their emergence. Primextra II magnum has been shown not to retard growth of cassava shoots (Alderelm, 2010). For the same treatments, since manual weeding was thrice, chemical weeding was carried out namely at the preemergence, that is two days after planting the stems, at 4 , at 10 weeks and at 16 weeks.

The heights of the weeds and the density per unit area were recorded before the second weeding, second spraying and before third weeding, third spraying to know the effectiveness of different methods on the plots. In doing these, 40 (forty) different points on each plot were randomly selected, at each of the 40 different points per plot, a circumference of $15 \mathrm{~m}^{2}$ at a radius of $7 \mathrm{~m}$, that is, about $78 \mathrm{~m}^{2}$ out of $100 \mathrm{~m}^{2}$ area of each point was considered for weed's heights and density. The weeds there were measured and the highest recorded from the selected tallest weeds at the circumferential point chosen.

The weed density was calculated as number of weeds per unit square metre within a point selected. Figure of merit which is defined as yield in tonnes/ha per unit total production cost (Feddes et al., 1999) for economic analysis were evaluated for different methods of cropping to determine the best methods that gave the farmer highest income. One-way ANOVA and pair t-tests were used for the statistical analysis of the relationship between the independent and dependent variables.

\section{RESULTS AND DISCUSSIONS}

Significant effects $(p<0.05)$ of the different types of weeding methods were observed $(p=0.008$ and 0.000 ) on the recorded tallest heights of weeds in the plots. The results of the average heights and their mean values were respectively were 33.65 and 24.76 before 2 nd weeding respectively in plots $O G$ and $C N$. Also, 33.00 and 21.10 before 3 rd weeding were mean values respectively in plots $\mathrm{OG}$ and $\mathrm{CN}$. The mean heights of the weeds at ten (10) different places to make four (4) values for each of the replicates before 2nd and 3rd weeding are shown in Table 1. The mean values of weeds' heights revealed that there were statistical differences within and between the methods of farming system and weeds' heights, Table 1. The heights of the tallest weeds at 40 different points on each plot revealed that plot OG had taller, more rapidly growing and developed weeds than plot $\mathrm{CN}$. The weeds reached their mean heights in plot $\mathrm{OG}$ were more than plot $\mathrm{CN}$, especially just before the second weeding with cumulative average height of $33.9 \mathrm{~cm}$ compare to $24.78 \mathrm{~cm}$ in $\mathrm{CN}$, this was the reason for the high density (weed stand count) of the weeds and the cumulative weed density. The mean heights of the tallest weeds at 40 different points on each plot show that plot $O G$ had taller, more rapidly growing and developed weeds than plot $\mathrm{CN}$ as shown in Table 1.

Also from Table 2, in conjunction with Table 1, no significant effects $(p>0.05)$ of the different types of weeding methods were observed $(p=0.269)$ on the recorded weed density in plot OG. However, there was significant effect $(p<0.05)$ of the types of weeding method on the weed density (weeds' stand count) in plot CN. The mean densities of the weeds at ten (10) different places to make four (4) values for each of the replicates before $2 \mathrm{nd}$ and 3rd weeding are shown in Table 2. The mean values of weeds' densities revealed that there were statistical differences within and between the methods of farming system and weeds' densities, Table 2. Table 2 shows high densities of weeds in plot OG than in plot $\mathrm{CN}$ at both times before second and third weeding, the canopy formation was continuous and the weeds were not able to develop more just before third weeding compare to their statuses just before the second weeding, this however was less developed in plot $\mathrm{CN}$.

The LAI monthly average values were consistently higher for conventional system than organic farming right from first month to the ninth month, 140 leaves, 135.4 leaves, Figure 1. From the average values of $\mathrm{LAI}$, the total average leaves in organic and conventional systems of farming were respectively $594.29 / 10$ cassava stands and $634.18 / 10$ cassava stands at 270th day, the percentage of the increment of the conventional over the organic was $39.89 \%$.

From the equations 1 and 2, the regression analysis show stronger relationship between different methods of farming and the crop heights average values, $R^{2}=$ 0.998 and 0.999 . This stronger relationship resulted 
in the development of the cassava shoots (canopy formation) in conventional farming than organic farming. Cassava shoots were able to form canopy quickly in plot $\mathrm{CN}$ than plot $\mathrm{OG}$. Their roots were able to penetrate the soil quickly because of the employed system of farming and they were also undisturbed during weeding since no hoeing was done (chemicals were used) and no soil trampling occurred, thereby, the soil organisms were not destroyed nor inactivated.

For organic,

$$
\begin{gathered}
\mathrm{Y}_{O G}=-0.60 \mathrm{X}^{3}+0.001 \mathrm{X}^{2}+0.0229 \mathrm{X}+1.444 \\
\mathrm{R}^{2}=0.998
\end{gathered}
$$

For conventional,

$$
\begin{gathered}
\mathrm{Y}_{C N}=-\mathrm{E}-080.7 \mathrm{X}^{3}+0.001 \mathrm{X}^{2}+0.274 \mathrm{X}+5.207 \\
\mathrm{R}^{2}=0.999
\end{gathered}
$$

In essence, it could be inferred that weeds densities in chemically weeded plots were more scanty compare to manually weeded plot.

Table 1: Mean values of Weeds' Heights in Plots OG and CN

\begin{tabular}{|l|c|c|c|c|c|c|c|c|}
\hline Plots & \multicolumn{2}{|c|}{$\begin{array}{c}\text { Weeds height in OG } \\
\mathrm{cm}\end{array}$} & \multicolumn{2}{|c|}{$\begin{array}{c}\text { Weeds height in CN } \\
\mathrm{cm}\end{array}$} & \multicolumn{2}{c|}{$\begin{array}{c}\text { Weeds height in OG } \\
\mathrm{cm}\end{array}$} & \multicolumn{2}{c|}{$\begin{array}{c}\text { Weeds height in CN } \\
\mathrm{cm}\end{array}$} \\
\cline { 2 - 9 } & $\begin{array}{c}\text { Before } \\
\text { 2nd } \\
\text { weeding }\end{array}$ & $\begin{array}{c}\text { Before } \\
\text { 3rd } \\
\text { weeding }\end{array}$ & $\begin{array}{c}\text { Before } \\
\text { 2nd } \\
\text { weeding }\end{array}$ & $\begin{array}{c}\text { Before } \\
\text { 3rd } \\
\text { weeding }\end{array}$ & $\begin{array}{c}\text { Before } \\
\text { 2nd } \\
\text { weeding }\end{array}$ & $\begin{array}{c}\text { Before } \\
\text { 3rd } \\
\text { weeding }\end{array}$ & $\begin{array}{c}\text { Before } \\
\text { 2nd } \\
\text { weeding }\end{array}$ & $\begin{array}{c}\text { Before } \\
\text { 3rd } \\
\text { weeding }\end{array}$ \\
\hline OG1 & $30.4^{\mathrm{a}}$ & $31.3^{\mathrm{a}}$ & $24.2^{\mathrm{a}}$ & $21.1^{\mathrm{a}}$ & $36.3^{\mathrm{a}}$ & $34.4^{\mathrm{a}}$ & $24.4^{\mathrm{b}}$ & $20.5^{\mathrm{a}}$ \\
\hline OG2 & $32.3^{\mathrm{a}}$ & $31.7^{\mathrm{a}}$ & $22.5^{\mathrm{a}}$ & $20.6^{\mathrm{a}}$ & $38.4^{\mathrm{a}}$ & $38.45^{\mathrm{b}}$ & $20.5^{\mathrm{a}}$ & $22.4^{\mathrm{b}}$ \\
\hline OG3 & $35.4^{\mathrm{b}}$ & $35.1^{\mathrm{b}}$ & $22.1^{\mathrm{a}}$ & $18.7^{\mathrm{a}}$ & $37.1^{\mathrm{a}}$ & $38.5^{\mathrm{b}}$ & $20.7^{\mathrm{a}}$ & $21.3^{\mathrm{b}}$ \\
\hline CN1 & $36.2^{\mathrm{b}}$ & $32.3^{\mathrm{a}}$ & $23.2^{\mathrm{a}}$ & $22.2^{\mathrm{a}}$ & $40.5^{\mathrm{b}}$ & $31.4^{\mathrm{c}}$ & $18.2^{\mathrm{a}}$ & $18.8^{\mathrm{c}}$ \\
\hline CN2 & $30.7^{\mathrm{a}}$ & $30.3 \mathrm{a}$ & $24.3^{\mathrm{a}}$ & $23.3^{\mathrm{a}}$ & $32.5^{\mathrm{c}}$ & $30.2^{\mathrm{c}}$ & $22.3^{\mathrm{c}}$ & $18.2^{\mathrm{c}}$ \\
\hline CN3 & $32.4^{\mathrm{a}}$ & $40.2^{\mathrm{c}}$ & $32.4^{\mathrm{b}}$ & $40.2^{\mathrm{b}}$ & $30.0^{\mathrm{c}}$ & $30.1^{\mathrm{c}}$ & $23.4^{\mathrm{c}}$ & $18.3^{\mathrm{c}}$ \\
\hline
\end{tabular}

Mean values with the same superscripts in the column are not significantly different $(p<0.05)$

In Table 3, the costs of labours, herbicides, rentage for equipment when calculated and compare for the two plots, (the same operational costs incurred are excluded), chemically (organically) weeded plot was less expensive in addition to its more efficiency. Table 3 also shows the yield after nine months for the tubers, plot $\mathrm{CN}$ had the highest yield (11.8) in tonne/ha than plot OG. Thus the total yield was $18 \%$ increased for the chemically weeded plot over the organically weeded plot. This is more than what UKCES (2011) said at the comparism between organic and conventional cropping systems: yields of crops in full organic production may be somewhat lower than that of conventional production. Most often cited are yield reductions of approximately 5\% to $10 \%$.

Manual weeding of cassava farm when monocropped is good based on the yield of 10 tonnes/ha, that is, 4 tonnes $(4000 \mathrm{~kg}$ ) per acre (compare with 11.8 tonnes/ha in chemically weeded) as recorded in the experiment despite non inclusion of fertilizer in its planting; but more expensive. Again it yielded less in tuber quantity at harvest when compare with the chemically weeded plot and this was shown in the harvest indices calculated for both plots. This variation depends on the crop variety, weather conditions, production methods and grower's expertise ingenuity.

The reasons for the reduced heights, low level of weed densities and lesser cost of weeding in $\mathrm{CN}$ than $O G$ and more tubers per plots in $C N$ and $O G$ are summarized below: 
Agric. Biol. J. N. Am., 2013, 4(2): 103-109

Table 2: Mean values of Weed Density (mean weed stand count) in plots OG and CN

\begin{tabular}{|l|c|c|c|c|c|c|c|c|}
\hline Plots & \multicolumn{2}{|c|}{$\begin{array}{c}\text { Weeds density in OG } \\
\text { / }\end{array}$} & \multicolumn{2}{|c|}{$\begin{array}{c}\text { Weeds density in CN } \\
/ \mathrm{m}^{2}\end{array}$} & \multicolumn{2}{|c|}{$\begin{array}{c}\text { Weeds density in OG } \\
/ \mathrm{m}^{2}\end{array}$} & \multicolumn{2}{|c|}{$\begin{array}{c}\text { Weeds density in CN } \\
/ \mathrm{m}^{2}\end{array}$} \\
\cline { 2 - 9 } & $\begin{array}{c}\text { Before } \\
\text { 2nd } \\
\text { weeding }\end{array}$ & $\begin{array}{c}\text { Before } \\
\text { 3rd } \\
\text { weeding }\end{array}$ & $\begin{array}{c}\text { Before } \\
\text { 2nd } \\
\text { weeding }\end{array}$ & $\begin{array}{c}\text { Before } \\
\text { 3rd } \\
\text { weeding }\end{array}$ & $\begin{array}{c}\text { Before } \\
\text { 2nd } \\
\text { weeding }\end{array}$ & $\begin{array}{c}\text { Before } \\
\text { 3rd } \\
\text { weeding }\end{array}$ & $\begin{array}{c}\text { Before } \\
\text { 2nd } \\
\text { weeding }\end{array}$ & $\begin{array}{c}\text { Before } \\
\text { 3rd } \\
\text { weeding }\end{array}$ \\
\hline OG1 & $91.1^{\mathrm{a}}$ & $100.1^{\mathrm{c}}$ & $85.2^{\mathrm{a}}$ & $90.5^{\mathrm{bc}}$ & $90.3^{\mathrm{a}}$ & $87.3^{\mathrm{a}}$ & $72.4^{\mathrm{a}}$ & $81.0^{\mathrm{a}}$ \\
\hline OG2 & $90.2^{\mathrm{a}}$ & $80.2^{\mathrm{a}}$ & $80.4^{\mathrm{ab}}$ & $85.3^{\mathrm{c}}$ & $101.4^{\mathrm{b}}$ & $86.4^{\mathrm{a}}$ & $62.4^{\mathrm{b}}$ & $90.4^{\mathrm{ab}}$ \\
\hline OG3 & $88.3^{\mathrm{b}}$ & $85.3^{\mathrm{ab}}$ & $82.3^{\mathrm{ab}}$ & $82.4^{\mathrm{c}}$ & $98.2^{\mathrm{ab}}$ & $90.5^{\mathrm{a}}$ & $60.3^{\mathrm{b}}$ & $62.2^{\mathrm{b}}$ \\
\hline CN1 & $88.1^{\mathrm{b}}$ & $78.2^{\mathrm{a}}$ & $75.5^{\mathrm{b}}$ & $81.5^{\mathrm{c}}$ & $97.2^{\mathrm{ab}}$ & $95.4^{\mathrm{b}}$ & $75.8^{\mathrm{ab}}$ & $58.3^{\mathrm{b}}$ \\
\hline CN2 & $90.2^{\mathrm{a}}$ & $90.2^{\mathrm{b}}$ & $75.4^{\mathrm{b}}$ & $75.5^{\mathrm{b}}$ & $97.3^{\mathrm{ab}}$ & $95.2^{\mathrm{b}}$ & $75.5^{\mathrm{ab}}$ & $58.1^{\mathrm{b}}$ \\
\hline CN3 & $101.3^{\mathrm{c}}$ & $90.3^{\mathrm{b}}$ & $76.2^{\mathrm{b}}$ & $65.3^{\mathrm{a}}$ & $102.1^{\mathrm{b}}$ & $96.2^{\mathrm{b}}$ & $85.3^{\mathrm{c}}$ & $48.3^{\mathrm{c}}$ \\
\hline
\end{tabular}

Mean values with the same superscripts in the column are not significantly different $(p<0.05)$

1. the roots were not at all disturbed throughout their existence thereby rapid leafiness of shoots in $O G$

2. the canopy was formed earlier in $\mathrm{CN}$ than in $O G$

3. with the weeds development in $O G$ and $\mathrm{CN}$, they couldn't have been better off than what they were compare to $O G$

4. with leaf area duration (LAD) increases (as a result of leafiness), the tuber development increases in $\mathrm{CN}$ than in $\mathrm{OG}$

5. rainfall were recorded in some of the days manual weeding were done, resulting in some of the uprooted weeds not fully destroyed, whereas, in chemical weeding, all the weeds were dying soon after systematic herbicides' application.

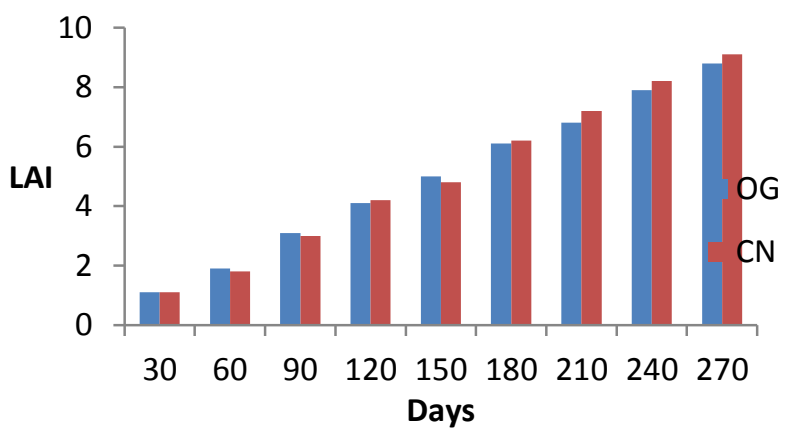

Fig 1: Average LAl values of cassava in organic and conventional cropping

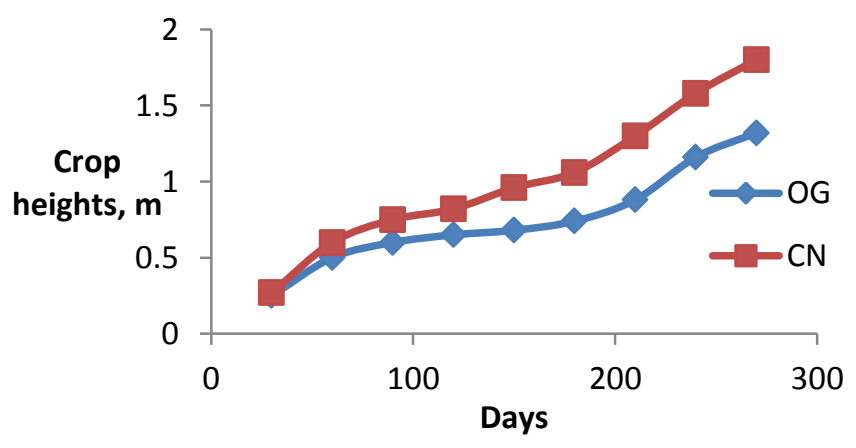

Fig 2: Average Crop heights in organic and conventional cropping 
Agric. Biol. J. N. Am., 2013, 4(2): 103-109

Table 3: Costs Implications and Yield (tonne/ha) of both Methods (excluding all common operational costs)

\begin{tabular}{|l|l|l|l|l|l|l|}
\hline \multirow{2}{*}{ Items } & \multicolumn{2}{l}{ OG (Costs in naira) } & \multicolumn{2}{l|}{ CN (Costs in naira) } \\
\cline { 2 - 7 } & $\begin{array}{l}\text { 1st } \\
\text { weeding }\end{array}$ & $\begin{array}{l}\text { 2nd } \\
\text { weeding }\end{array}$ & $\begin{array}{l}\text { 3rd } \\
\text { weeding }\end{array}$ & $\begin{array}{l}\text { 1st } \\
\text { weeding }\end{array}$ & $\begin{array}{l}\text { 2nd } \\
\text { weeding }\end{array}$ & 3rd weeding \\
\hline Herbicides & - & - & - & 2,400 & 2,400 & 2,400 \\
\hline Labour in spraying & - & - & - & 2,200 & 2,200 & 2,000 \\
\hline Hoeing & 10,000 & 9,000 & 9,500 & - & - & - \\
\hline Sprayer rentage & - & - & - & 300 & 300 & 300 \\
\hline Water provision & - & - & - & 400 & 400 & 400 \\
\hline Total, naira & 10,000 & 9,000 & 9,500 & 5,300 & 5,300 & 5,100 \\
\hline $\begin{array}{l}\text { Total cost of weeding, } \\
\text { naira }\end{array}$ & 28,500 & & 15,700 & & \\
\hline Total yield, tonne/ha & 10 & & 11.8 & \\
\hline
\end{tabular}

'costs of labour and materials in lleogbo, Ayedire LGA, Osun State'

Table 4: Figure of merit for Economic Analysis

\begin{tabular}{|l|c|c|}
\hline & Plot OG & Plot CN \\
\hline Figure of merit, tonne/ha naira & $3.51 \times 10^{-4}$ & $7.52 \times 10^{-4}$ \\
\hline
\end{tabular}

Economic Analysis: The detail economic analysis was conducted. Table 3 show that at plot $\mathrm{CN}$, the highest yield in tonnes/ha of cassava yield was 11.8 with production cost (excluding costs of seed, land clearing, planting, fertilizing and all that are common to both methods of weeding) of 11,600 naira. Figure of merit which is defined as yield in tonnes/ha per unit total production cost (Feddes et al., 1999) evaluated for the plots and shown in Table 4. The highest figure of merit was $7.52 \times 10^{-4}$ tonnes/ha Naira for plot CN while plot $O G$ had $3.51 \times 10^{-4}$ tonnes/ha Naira. This was $214 \%$ increment in the figure of merit for the chemically sprayed plot CN over the manually weeded plot OG.

\section{CONCLUSIONS}

The following conclusions were arrived at in the course of the research:

LAI monthly average values were consistently higher for conventional system than organic farming; the percentage of the increment of the conventional over the organic was $39.89 \%$.

There was stronger relationship between systems of farming and the LAl average values. This stronger relationship resulted in quick development of the cassava canopy formation in conventional farming than organic farming. There was also stronger relationship between different methods of farming and the crop heights. The total yield was $118 \%$ increased for the chemically weeded plot $\mathrm{CN}$ over the manually weeded plot OG.

Since the overall objective of cultivation is profit, the results of this study show that conventionally cultivated, chemically weeded farming systems was better in yield.

\section{ACKNOWLEDGEMENT}

All the entire people of Mamu/Abimbola Village (via lleogbo) in Ayedire LGA of Osun State are highly appreciated for their cooperative attitudes during the course of the experiment.

\section{REFERENCES}

Alderelm Ltd Sales Terms (2010). Working and Growing together, Chemicals for Agriculture. Lagos, Nigeria.

American Society of Agronomy- ASA. (2009). Can organic cropping systems be as profitable as conventional systems?. Science Daily. Retrieved 25/12/2012 http://www.sciencedaily.com/releases. 
Chavas J-P, Posner, J. L and Hedtcke, J. L. (2009). Organic and Conventional production systems in the Wisconsin Integrated cropping systems trial: II. Economic and risk analysis 1993. Agronomy Journal, 101(2):288

Chen, J. M., Rich, P. M., Gower, S. T., Norman, J. M. And Plummer, S., 1997. Leaf Area Index of Boreal Forests: Theory, Techniques, and Measurements. Journal Geophys. Res.-Atmos., 102: 29429-29443.

CSAD (2005). Adding New Values to Cassava - A New Agricultural Revolution, Centre for Sustainable Agricultural Development, Lagos, Nigeria

Cutini, A., Matteucci, G. and Mugnozza, G. S., 1998. Estimation of Leaf Area Index With the Li-Cor LAI 2000 in Deciduous Forests. Forest Ecol. Mgmt., 105: 55-65.

Feddes J.J.R. Emmanuael R.H, Macgovern R.H and Zuidoff M.J. 1999. Broiler Performance, weight variance, feed and water intake and carcass quality at different stocking densities. Poultry Research Centre News- (2): 13 and 23 Broiler Breeder on line http//www.agric.gov.ab.ca/aprc/

IITA (1990). Cassava in the Tropical Africa- A Reference Manual, International Institute of Tropical Agriculture, Ibadan

Kumar R (1984). Insect Pest Control; with special reference to African Agriculture, 2nd Edition, Athenaeum Press Ltd, Gateshead, Great Britain

Lamidi W. A. 2005. Impacts of Agricultural Education on Farm Mechanisation in Osun State in 2003 and
2004 Farm years; Journal of General Studies in Education (JOGSE). 4 (1) : 112-117

Lamidi W. A. 2005. Introduction to Crop Production, First Edition, Station Road, Osogbo, Nigeria, Remi Osarayi and Sons Enterprises.

Magani, I. E. and Shave, P. A. (2011). Economics of Tillage systems and herbicides in lowland rice production at Makurdi, southern guinea savanna, Nigeria. Agriculture and Biology Journal of North America, 2(6): 929-934

Matthew G.A (1981). Development in Pesticides Application for Small Scale Farmers in the Tropics. Outlook in Agriculture 10 (7), 345-349

MoE.BC- Ministry of Environment, British Columbia (2006). British Columbia Crop Production Guides. http://www.agf.gov.bc.ca/pesticides/a

Olabiyi T.I (2004). Diseases of Food Crops and their Control Principles. Amograf Publishers, lle-Ife, Nigeria, page 54 .

Olabode, O. S., Adesina, G. O. and Olapeju, T. R. (2011). A survey of Agricultural Chemical available to farmers in South Western Nigeria. International Journal of Agricultural Economics \& Rural Development, 4(1): 2011, 12-18.

University of Kentucky Cooperative Extension Service (UKCES), 2011. Educational programme of the Kentucky Cooperative Extension Service, College of Agriculture.

http://www.kyagr.com/marketing/plantmktg/organic/ind ex.htm 